\title{
Spatial and temporal distribution and microhabitat use of aquatic breeding amphibians (Anura) in a seasonally dry tropical forest in Chamela, Mexico
}

\author{
Martha I. Luna-Gómez ${ }^{1}$, Andrés García ${ }^{2 *} \&$ Georgina Santos-Barrera ${ }^{3}$ \\ 1. Posgrado en Ciencias Biológicas, Instituto de Biología, Universidad Nacional Autónoma de México. Apartado Postal \\ 70-153, Ciudad de México, Código Postal 04510. México; moxybelis25@gmail.com \\ 2. Estación de Biología Chamela, Instituto de Biología, Universidad Nacional Autónoma de México. Apartado Postal 21, \\ San Patricio, Melaque, Jalisco, Código Postal 48980, México; chanoc@ib.unam.mx \\ 3. Museo de Zoología, Facultad de Ciencias, Universidad Nacional Autónoma de México. Apartado Postal 70-399, \\ Ciudad de México, Código Postal 04510. México; gsantos@ecologia.unam.mx
}

Received 07-VI-2016. C Corrected 24-III-2017. Accepted 25-IV-2017.

\begin{abstract}
The distribution of amphibians is affected by abiotic and biotic factors, availability of resources and the characteristics of reproductive sites. In particular, reproductive activity of aquatic-breeding anurans that inhabit tropical dry areas is affected by rainfall, which determines the availability and quality of reproductive sites. In this study, we analyzed the spatial and temporal distribution of anurans with indirect development in a tropical dry forest in Western Mexico, during two rainy seasons (July 10-October 4, 2013, and June 26-September 26, 2014). We collected data on the occupancy and reproductive activity of 15 species in four temporary streams, and evaluated their relationship with precipitation, humidity and temperature. We determined richness, abundance and diversity of species in each stream; we also identified differences in the reproductive strategies and microhabitats used by the species. The most abundant species were: Tlalocohyla smithii and Exerodonta smaragdina, whereas the least abundant were Leptodactylus melanonotus and Incilius mazatlanensis. Species richness, abundance and reproductive activity peaked alongside the stream with the greatest number of breeding sites (e.g. pools). We found temporal segregation in the occupancy and reproductive activity of species in all streams which were mainly associated with precipitation. However, occupancy and reproductive activity of some species overlapped up to four weeks during part of the breeding season. Most species used specific substrates for particular reproductive activities (e.g. oviposition), but used a range of microhabitats (leaf-litter, water, rocks, branches, leaves, logs, etc.) for others (e.g. calling). We discuss these behavioral differences as factors that facilitate coexistence of species in this environment in the rainy season. Rev. Biol. Trop. 65 (3): 1082-1094. Epub 2017 September 01.
\end{abstract}

Key words: amphibians, reproductive strategies, environmental seasonality, reproductive activity, indirect development.

Reproductive activity of anuran species is strongly influenced by abiotic factors such as precipitation and temperature (Moreira \& Lima, 1991; Bertoluci, 1998; Ford \& Scott, 2006; Saenz, Fitzgerald, Baum, \& Conner 2006; Schalk \& Saenz, 2016). It is further suggested that community structure is associated with reproductive phenology, as the sequence and variations of these events largely determine species composition at the local scale (Sáenz et al., 2006; Afonso \& Eterovick, 2007). Anuran species that coexist present important differences in morphology, physiology, and behavior (Crump, 1974; Pough, Stewart, \& Thomas, 1977; Cardoso, Andrade, \& Haddad, 1989; Afonso \& Eterovick, 2007). During the reproductive season, resource overlapping within the community becomes more intense (Bertoluci \& Rodrigues, 2002), therefore species can exhibit temporal or spatial 
segregation or partial/complete overlap in the use of resources (Rossa-Feres \& Jim, 2001). Temporal partitioning can be directly related to each region's climate, particularly precipitation (Vasconcelos \& Rossa-Feres, 2005; Curi, Céspedez, \& Álvarez, 2014), since the unpredictability and the frequency of rains can limit temporal distribution of some amphibian species, by affecting the quantity and quality of aquatic environments used for reproduction (Bernarde \& Anjos, 1999; Santos, Rossa-Feres, \& Asatti, 2007).

Tropical dry forest in the Chamela region, on the coast of Jalisco in Western Mexico, is characterized by a prolonged dry season, and a marked seasonality in rainfall, with most precipitation occurring from July to October (Bullock, 1986). Rainfall varies in intensity and frequency between years, being mainly associated with hurricanes and tropical storms (García-Oliva, Maass, \& Galicia, 1995). In Mexico, tropical dry forest encompasses a third of vertebrate species richness and endemism (Ceballos \& Garcia, 1995). However, despite the importance of tropical dry forest for the conservation of Mexican biodiversity, it is one of the most threatened ecosystems in the Neotropics, mainly due to current high deforestation rates (Ceballos \& García, 1995; Trejo \& Dirzo, 2000). Although herpetofauna in the Chamela region have been intensively studied (Casas-Andreu, 1982; Garcia \& Ceballos, 1994; Ramirez-Bautista, 1994; Ramirez-Bautista \& Garcia, 2002; García, 2003; SuazoOrtuño, Alvarado-Díaz, \& Martínez-Ramos, 2008), no information exists on the spatial and temporal distribution of species, or the factors influencing their occurrence, in streams and at breeding sites in particular. The exception is a short-term (one month) paper by Ford and Scott (2006) that focused on the occurrence of aquatic breeding anurans at reproductive sites, who determined that tadpoles of six species were spatially partitioned in the habitat, and found no differences in tadpole assemblages in forested and non-forested sites. The marked seasonality in rainfall at Chamela, and the sporadic pattern of rainfall during the rainy season mean that flooding of temporary streams and breeding activity of anuran species depend on the occurrence of heavy rains that would clearly influence the spatial and temporal distribution of aquatic breeding anurans. Information on the factors influencing aquatic breeding anuran is necessary to determine conservation strategies not only for this group in particular, but for all amphibian species associated with tropical dry forest, as well as to provide theoretical information on the effects of seasonality on species distribution patterns, and to understand the responses of communities to current global problems such as climate change.

In this study, our main goals were to: 1) describe the structure of an assemblage of 15 species of anurans with indirect development in four temporary streams during their reproductive season; 2) evaluate the relationship between climatic variables (temperature, precipitation and humidity) and anuran occupancy and reproductive activity in those four streams; and finally, 3) determine the temporal and spatial occupancy, abundance, and diversity as well as microhabitat use by species during reproductive activities.

\section{MATERIALS AND METHODS}

Study area: This study was conducted in the Estación de Biología Chamela of the Instituto de Biología, Universidad Nacional Autónoma de México (19³0' - 19³2' N \& $\left.105^{\circ} 03^{\prime}-105^{\circ} 05^{\prime} \mathrm{W}\right)$ on the Jalisco coast, Mexico. The Chamela station is part of the Reserva de la Biosfera Chamela-Cuixmala, which protects 13142 ha of tropical dry forest and associated ecosystems (Ceballos, Szekely, García, Rodríguez, \& Noguera, 1999). The climate is tropical sub-humid with a prolonged dry season of about eight months and a welldefined rainy season with $85 \%$ of the annual precipitation occurring from July to October (Bullock, 1986). Average annual precipitation and temperature is $748 \mathrm{~mm}$ and $25{ }^{\circ} \mathrm{C}$, respectively. The landscape is comprised of small hills dominated by deciduous forest vegetation, with semi-deciduous forest vegetation 
restricted to small valleys (Lott, Bullock, \& Solis-Magallanes, 1987). Other vegetation types in the reserve include xerophilus scrub, wetlands, grassland and mangrove (Ceballos et al., 1999). This region comprehends considerable vertebrate species diversity, including 19 anuran species, 11 of which are endemic to Mexico, and 15 have indirect development (García \& Ceballos, 1994; García \& Cabrera-Reyes, 2008).

Data collection: This study was carried out during two rainy seasons, from July 10 to October 4, 2013, and June 26 to September 26, 2014. We established five transects along the main streambeds (known locally as 'arroyos') and watersheds at the Chamela Station: $1 \mathrm{~km}$ long transects in each of three streams Colorado, Hornitos and Zarco, and two transects of $500 \mathrm{~m}$ long along the watershed drainages known as Cuenca 2 and Cuenca 3 (BC watersheds). Each line-transect was divided into 50 $\mathrm{m}$ sections, giving 80 survey sections in total, with 20 sections in the streams, and 10 in each of the two watersheds. After the first heavy rain (>30 mm), we surveyed all transects to locate potential sites or pools for amphibian reproduction, and to record any signs of breeding activity (calling males, adults in amplexus, presence of eggs and/or larvae). Each pool located was georeferenced, and individually marked with flagging. We recorded the site, survey section, and chronological order in which the pools formed and were found.

Once we located all breeding sites along the transect survey sections, we defined a time schedule to ensure that all five line-transects were surveyed twice a week, for a period of one to two hours each. All surveys were conducted at night, from 21:00 - 02:00 h. During each survey, three samplers walked along the transect at a slow pace looking for adult anurans on the streambed and within a $2 \mathrm{~m}$ band along each bank, as well as those present in pools. Anurans were detected using simultaneous visual encounter surveys and auditory sampling (Crump \& Scott, 1994; Zimmerman, 1994). For each individual anuran found, we recorded the species, location, activity (calling, amplexus, resting), and microhabitat according to type of substrate (sand, leaf-litter, rock and water) or plant life-form (tree, grass, bromeliads, agaves, herbs). This survey effort consisted of a total of 25 weeks of continuous field work during two rainy seasons, comprising 120 nocturnal surveys in 2013, and 130 nocturnal surveys in 2014. This resulted in 1800 and 1950 personhours of visual encounter surveys in 2013 and 2014, respectively (Supplementary Material).

Using data collected from all survey sections along each transect, we calculated species richness and the number of individuals of each species per transect. We used nomenclature in accordance with Frost (2016) Amphibian Species of the World. Information on habitat use was collected to determine potential differences in the occurrence of anuran species across the different microhabitats. We also evaluated whether species conducted specific activities (calling, amplexus and resting) in different microhabitats at the pools, and whether there is habitat partitioning among species.

Climatic variables: We obtained information on precipitation, temperature and relative humidity from the Chamela meteorological station, to explore the relationship between these variables and the reproductive activity and occupancy of anuran species. We calculated total weekly and accumulated precipitation, as well as weekly averages of maximum and minimum temperature, and relative humidity for each sampling season. We then analyzed the relationship between weekly climate variables and weekly occurrence of each anuran species.

We determined species richness and the number of individuals of each species per stream and watershed. Species diversity was estimated using the three indices of Shannon-Wiener, Simpson, and diversity of order one. The Jaccard species similarity index was used to compare composition of anuran species between sites. To explore the relationship between abiotic variables and anuran reproduction activity we conducted a Spearman correlation analysis of number of individuals 
of each species per week with weekly accumulated precipitation. To describe the reproductive phenology of the anuran assemblage we used weekly records of adult activity related to weekly and cumulative precipitation for each sampling year.

\section{RESULTS}

Reproductive sites: We located 161 pools formed during the 2013 rainy season, and 147 pools in 2014. The number of pools formed per survey section was higher in Arroyo Zarco in both years (65 and 59, respectively), than in Arroyo Colorado (16 and 30), Arroyo Hornitos (26 and 24), and the two watershed drainages combined (Cuencas BC: 54 and 44, respectively). During 2013, about $45 \%$ of sites (72 pools) were used by anurans for reproduction at some point (34 in Zarco, 9 in Colorado, 13 in Hornitos and 16 in Cuencas BC), whereas in 2014 only about $18 \%$ ( 27 pools) were used (12 in Zarco, 4 in Colorado, 4 in Hornitos, and 7 in Cuencas BC).

\section{Species richness, number of individuals} of each species, composition and diversity: During nocturnal surveys, we obtained a total of 7313 observations of individuals belonging to 15 anuran species, representing 12 genera and five families (Table 1). The most diverse family was Hylidae with 8 species, which also included the most abundant species of Tlalocohyla smithii and Exerodonta smaragdina (Table 1). The species of Leptodactylus melanonotus (Leptodactylidae), Incilius mazatlanensis and Rhinella horribilis (Bufonidae) had the least number of individuals (Table 1). The occurrence and the number of individuals of each species was not uniform in all at the sampling

TABLE 1

Number of individuals, species richness and diversity indices for anuran species by survey site at Estación de Biología Chamela, Jalisco, Mexico

\begin{tabular}{llccccc} 
& \multicolumn{1}{c}{ Species } & Cuencas & Arroyo & Arroyo & Arroyo & $\begin{array}{c}\text { Total } \\
\text { abundance }\end{array}$ \\
Bufonidae & Incilius marmoreus & 39 & 128 & 146 & 475 & 788 \\
Bufonidae & Incilius mazatlanensis & 0 & 1 & 7 & 19 & 27 \\
Bufonidae & Rhinella horribilis & 19 & 2 & 5 & 7 & 33 \\
Hylidae & Agalychnis dacnicolor & 230 & 135 & 157 & 480 & 1002 \\
Hylidae & Dendropsophus sartori & 17 & 0 & 5 & 42 & 64 \\
Hylidae & Diaglena spatulata & 51 & 37 & 38 & 137 & 263 \\
Hylidae & Exerodonta smaragdina & 167 & 311 & 190 & 637 & 1305 \\
Hylidae & Smilisca baudinii & 82 & 120 & 127 & 283 & 612 \\
Hylidae & Smilisca fodiens & 21 & 21 & 31 & 35 & 108 \\
Hylidae & Tlalocohyla smithii & 44 & 413 & 95 & 1075 & 1627 \\
Hylidae & Trachycephalus typhonius & 0 & 38 & 15 & 35 & 88 \\
Leptodactylidae & Leptodactylus melanonotus & 1 & 2 & 0 & 10 & 13 \\
Microhylidae & Hypopachus ustus & 95 & 179 & 139 & 377 & 790 \\
Microhylidae & Hypopachus variolosus & 39 & 106 & 105 & 265 & 515 \\
Ranidae & Lithobates forreri & 7 & 8 & 0 & 63 & 78 \\
Number of species & & 13 & 14 & 13 & 15 & 394 \\
Number of individuals & & 812 & 1501 & 1060 & 3940 \\
Shannon-Weaver & & 2.1 & 2.04 & 2.19 & 2.12 &
\end{tabular}

The total corresponds to the sum of the four sampled sites: numbers are based on observed female and male adults during the surveys. 
TABLE 2

Jaccard species similarity index for anuran species among sampling sites at Estación de Biología Chamela, Jalisco, Mexico

\begin{tabular}{lccc}
\multicolumn{1}{c}{ Sites } & Cuencas BC & Colorado & Hornitos \\
Cuencas BC & 1 & & \\
Colorado & 0.85 & 1 & \\
Hornitos & 0.84 & 0.85 & 1 \\
Zarco & 0.86 & 0.93 & 0.86 \\
\hline
\end{tabular}

sites (Table 1). Ten of fifteen anuran species were recorded in all sites, whereas five species were found in only three sites (Table 1). The number of individuals of each species was on average three to five times higher in Arroyo Zarco than in other sites (Table 1). Species richness was highest in Arroyo Zarco, although diversity indices were similar among sites, but were slightly higher in Arroyo Hornitos (Table 1). The Jaccard similarity indices also indicated a high similarity of anuran species among sites, particularly between Zarco and Colorado (Table 2). When we compared the relative number of individuals reported for each species in a particular site with respect to the total number recorded for that species in all sites, it was clear that the majority of individuals of most species were observed in Arroyo Zarco (average $53.8 \%$ of individuals per species; Fig. 1). The exceptions were $R$. horribilis and Trachycephalus typhonius found mainly in the Cuencas BC and Arroyo Colorado, respectively.

Correlations between abiotic factors and anuran occupancy of reproductive sites: Multiple Spearman correlation tests found that reproductive activity of species such as Agalychnis dacnicolor, Hypopachus ustus and Smilisca baudinii, were positively correlated with maximum temperature (Spearman $r=$ $0.553,0.464,0.41$ respectively), but negatively correlated with an increment in accumulated precipitation (Spearman $r=-0.841,-0.589$, -0.479 , respectively). This group of species was found active from June to August, with a subsequent decline in activity when streambeds had running water. Even though the number of active $S$. baudinii individuals increased after heavy rains $(>25 \mathrm{~mm}$ ), there was no significant correlation between number of individuals of this species and weekly precipitation. In contrast, abundance of E. smaragdina and $T$. smithii were positively correlated with accumulated precipitation (Spearman $=0.672$, and 0.687 , respectively) and relative humidity (Spearman $=0.585$, and 0.623, respectively), and negatively correlated with the maximum temperature $($ Spearman $=-0.776$, and -0.774 ,

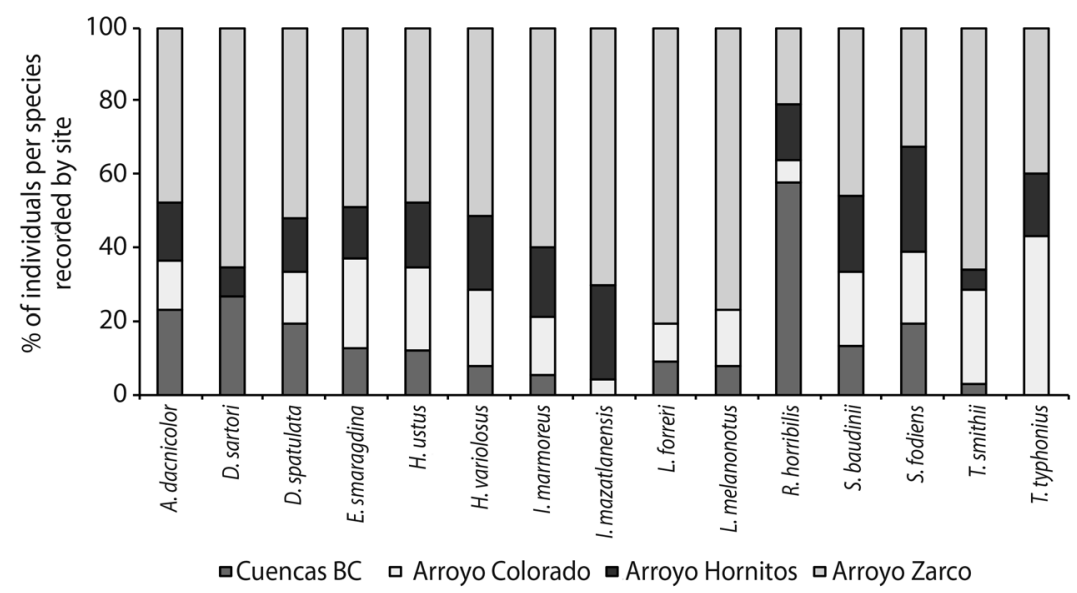

Fig. 1. Percentile distribution of individuals of each species by sampling sites at Estación de Biología Chamela, Jalisco, Mexico. 
respectively). For these two species, the number of individuals increased during September to October, when arroyo streams filled with water after accumulated rainfall exceeded 300 $\mathrm{mm}$. These species were considered prolonged breeding species that reproduce several times throughout the rainy season (Fig. 2). Activity of six species, Diaglena spatulata, $H$. variolosus, I. marmoreus, I. mazatlanensis, S. fodiens and
T. typhonius were positively correlated with weekly precipitation (Spearman $=0.489,0.586$, $0.540,0.576,0.460,0.418$, respectively). These species were active exclusively during or after heavy rains (generally $>30 \mathrm{~mm}$ ), and were considered explosive breeders.

Based on these results, we grouped species according to two main reproductive strategies of prolonged or explosive breeders. Species
Agalychnis dacnicolor

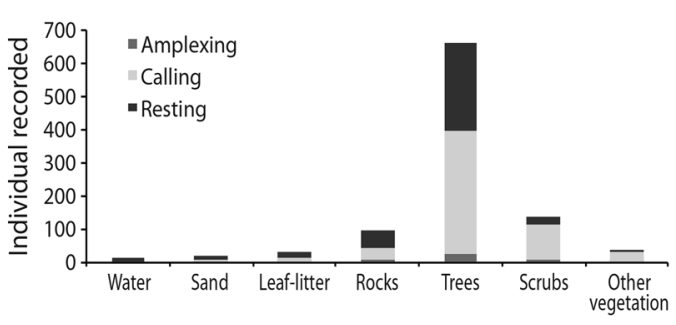

Exerodonta smaragdina

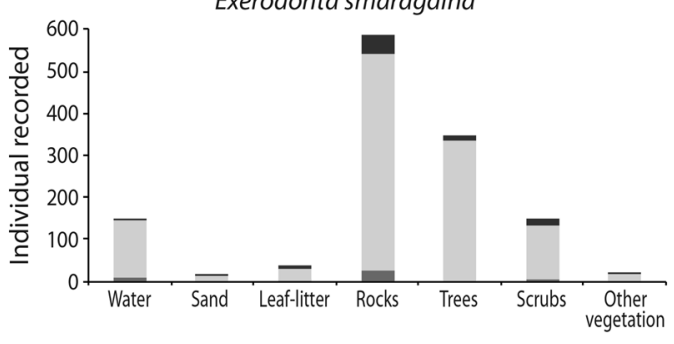

Tlalocohyla smithii
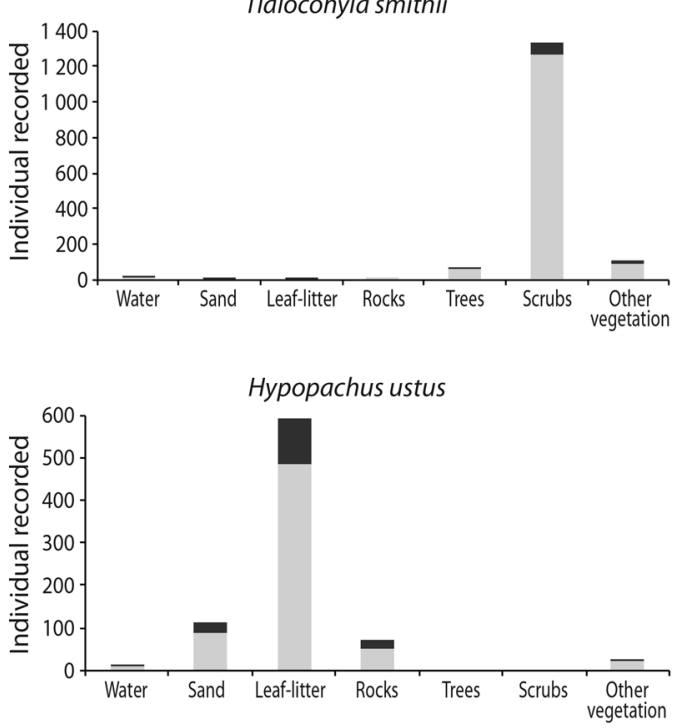

Diaglena spatulata

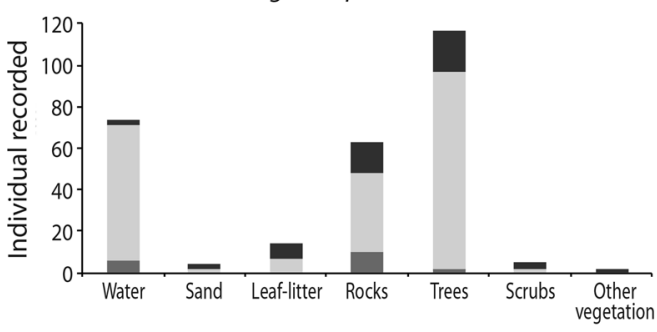

Smilisca baudinii

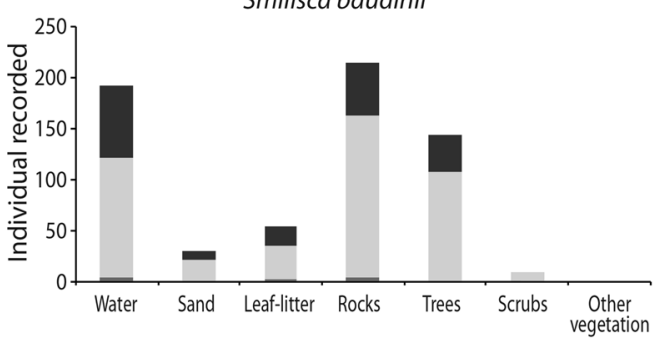

Hypopachus variolosus

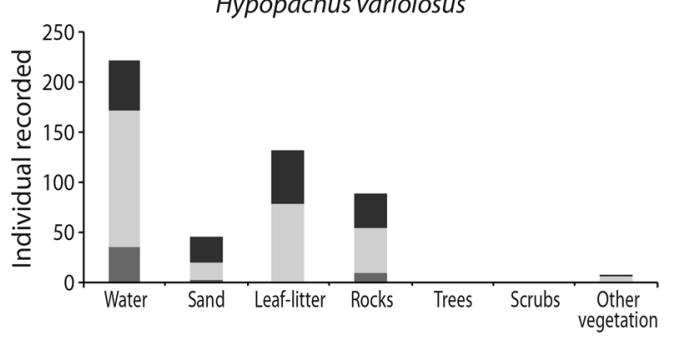

Incilius marmoreus

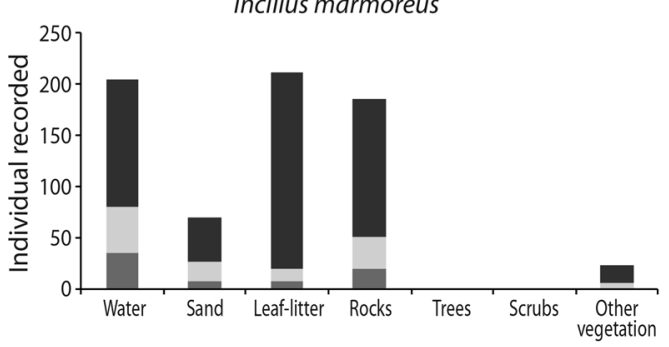

Fig. 2. Activity and use of microhabitat of more abundant species of anurans at Estación de Biología de Chamela, Jalisco, Mexico. 
with prolonged breeding could be further subdivided into two groups based on the correlations of reproductive activity with climate variables: 1) species that are positively correlated with accumulated precipitation and humidity, and negatively correlated with temperature; and 2) species that are negatively correlated with the accumulated precipitation and positively correlated with temperature. We could not determine the temporal reproductive strategy of Lithobates forreri, Dendrosophus sartori, and $R$. horribilis as their activity was not correlated with any of the climate variables studied.

Temporal segregation: Weekly records of males of each species calling at all sites showed that there was a tendency towards species replacement at breeding sites throughout the rainy season. The species that were reproductively active during the first weeks of the rainy season included one of the most abundant species recorded, H. ustus, and large-bodied hylids such as $A$. dacnicolor and $S$. baudinii. The small-bodied hylids with greatest overall abundance, such as E. smaragdina and $T$. smithii, were more active during the late rainy season, when cumulative rainfall exceeded $300 \mathrm{~mm}$, and the arroyos formed into strong flowing streams (Table 3). However, there was generally an overlap in the occurrence of most anuran species that was associated with the occurrence of strong weekly rainfall (Table 3).

TABLE 3

Number of calling males of more abundant species during the sampling weeks in relation to weekly and accumulated rainfall in 2013 and 2014

\begin{tabular}{|c|c|c|c|c|c|c|c|c|c|c|c|c|c|}
\hline \multicolumn{14}{|c|}{ Sampling weeks during 2013 (10 July to 03 October) } \\
\hline Species & 1 & 2 & 3 & 4 & 5 & 6 & 7 & 8 & 9 & 10 & 11 & 12 & \\
\hline Agaychnis dacnicolor & 71 & 35 & 18 & 28 & 22 & 23 & 24 & 16 & 12 & 13 & 7 & 3 & \\
\hline Diaglena spatulata & 9 & 4 & 6 & 22 & 10 & 87 & 8 & 12 & 0 & 1 & 2 & 1 & \\
\hline Exerodonta smaragdina & 2 & 2 & 1 & 0 & 0 & 1 & 77 & 282 & 55 & 163 & 162 & 84 & \\
\hline Hypopachus ustus & 73 & 36 & 25 & 48 & 44 & 57 & 73 & 30 & 3 & 1 & 0 & 0 & \\
\hline Hypopachus variolosus & 1 & 1 & 0 & 8 & 0 & 52 & 55 & 44 & 3 & 11 & 0 & 0 & \\
\hline Incilius marmoreus & 30 & 0 & 0 & 8 & 3 & 84 & 37 & 95 & 3 & 0 & 0 & 0 & \\
\hline Smilisca baudinii & 9 & 5 & 9 & 34 & 25 & 113 & 5 & 45 & 0 & 1 & 0 & 0 & \\
\hline Tlalocohyla smithii & 3 & 0 & 0 & 1 & 0 & 0 & 13 & 125 & 175 & 177 & 52 & 270 & \\
\hline Individuals recorded & 198 & 83 & 50 & 149 & 104 & 417 & 292 & 649 & 251 & 367 & 223 & 358 & \\
\hline Number of species & 8 & 6 & 5 & 7 & 5 & 7 & 8 & 8 & 6 & 7 & 4 & 4 & \\
\hline Weekly rainfall (mm) & 11 & 6 & 0 & 35 & 19 & 39 & 35 & 85 & 31 & 16 & 0 & 0 & \\
\hline Accumulated rainfall (mm) & 113 & 119 & 119 & 154 & 173 & 212 & 247 & 332 & 363 & 399 & 399 & 399 & \\
\hline \multicolumn{14}{|c|}{ Sampling weeks during 2014 (26 June to 26 September) } \\
\hline Species & 1 & 2 & 3 & 4 & 5 & 6 & 7 & 8 & 9 & 10 & 11 & 12 & 13 \\
\hline Agaychnis dacnicolor & 93 & 48 & 47 & 40 & 29 & 62 & 27 & 20 & 45 & 23 & 10 & 6 & 7 \\
\hline Diaglena spatulata & 20 & 0 & 0 & 0 & 0 & 12 & 3 & 2 & 3 & 14 & 15 & 0 & 0 \\
\hline Exerodonta smaragdina & 2 & 1 & 0 & 0 & 0 & 0 & 1 & 0 & 0 & 41 & 293 & 116 & 41 \\
\hline Hypopachus ustus & 53 & 16 & 28 & 49 & 25 & 60 & 68 & 4 & 22 & 42 & 3 & 4 & 1 \\
\hline Hypopachus variolosus & 176 & 12 & 6 & 27 & 3 & 8 & 2 & 0 & 19 & 27 & 53 & 2 & 0 \\
\hline Incilius marmoreus & 136 & 22 & 13 & 5 & 6 & 25 & 4 & 0 & 1 & 33 & 85 & 10 & 3 \\
\hline Smilisca baudinii & 91 & 13 & 28 & 10 & 31 & 36 & 22 & 13 & 19 & 23 & 23 & 4 & 1 \\
\hline Tlalocohyla smithii & 9 & 0 & 0 & 0 & 0 & 0 & 1 & 0 & 0 & 8 & 208 & 155 & 359 \\
\hline Individuals recorded & 580 & 112 & 122 & 131 & 94 & 203 & 128 & 39 & 109 & 211 & 690 & 297 & 412 \\
\hline Number of species & 8 & 6 & 5 & 5 & 5 & 6 & 8 & 4 & 6 & 8 & 8 & 7 & 6 \\
\hline Weekly rainfall (mm) & 139 & 2 & 0 & 4 & 14 & 18 & 12 & 0 & 22 & 46 & 196 & 136 & 71 \\
\hline Accumulated rainfall $(\mathrm{mm})$ & 160 & 162 & 162 & 166 & 180 & 198 & 210 & 210 & 232 & 255 & 451 & 588 & 660 \\
\hline
\end{tabular}


Microhabitat use: $A$. dacnicolor showed a strong association with logs, branches, and leaves of trees near the pools, where it was found calling, resting, or in amplexus, although the species also occurred in smaller proportion in bushes, on rocks, and other substrates (Fig. 2). Clutches were observed on leaves, trunks, shrubs and rocks next to the pools. D. spatulata was more frequently observed in the water of pools or on nearby rocks, but was also found calling and resting on tree trunks. Amplexing pairs were also observed in pools and on rocks (Fig. 2). Calling males and amplexing pairs of E. smaragdina were found generally on rocks emerging above the water flow or directly in water in shallow areas of streams $(<2 \mathrm{~cm})$, but resting individuals were observed more frequently on small rocks, tree branches, leaves and shrubs near streams (Fig. 2). Individuals of $S$. baudinii were found mainly in the pools and nearby rocks when calling, resting or in amplexus, although sometimes individuals occurred on other substrates (Fig. 2). Clutches of this species were always found at the water surface of pools. The species T. smithii was associated almost exclusively with tree leaves, shrubs, and grass near streams, when singing, resting, and during amplexus (Fig. 2). No clutches were observed for the three species of D. spatulata, E. smaragdina, and T. smithii.

When calling, resting or in amplexus, $H$. ustus was always found at ground level, either on litter (most individuals), on the sand in the dry stream bed, or in cavities under rocks (Fig. 2). Clutches were found on the surface of the pools. By comparison, individuals of $H$. variolosus were found calling and amplexing almost exclusively in the pools, while resting individuals were observed in water, leaf-litter, and under rocks, or at the base of grassy vegetation in the dry sandy streambeds (Fig. 2). Clutches of this species were observed on the water surface of pools. Resting I. marmoreus were observed frequently on leaves, rocks, and in the water of pools, while those calling or amplexing were observed mainly in the water of pools and rocks close to the pools (Fig. 2).
Clutches of this species were observed on the surface of pools.

\section{DISCUSSION}

In terms of species richness and number of individuals recorded for each species by site, Arroyo Zarco presented the highest number of species and individuals, and was also the site with the highest number of pools, and pools used for reproduction. Therefore, the higher anuran occurrence in the transect along Arroyo Zarco could be associated with the greater availability of pools. By comparison, while we also recorded a considerable number of pools in the watersheds (Cuencas BC), these had features of greater altitude and slope that could make them less accessible for some anuran species and individuals.

While species composition of anurans was similar among streams, we did not record $T$. typhonius in the watersheds, probably due to the predominant vegetation along these streams (terrestrial bromeliads, cactus and herbaceous vegetation), given that this is mainly an arboreal species. On the other hand, A. dacnicolor another arboreal species, was frequently found in these watersheds but associated with rocky ponds. In Arroyo Hornitos there were no records of $L$, forreri and L. melanonotus, although these species were generally observed in low numbers at other streams during the study. Some studies have reported that these two species are clearly associated with disturbed or open habitats, and with water bodies that have long, stable hydroperiods (Carrasco, 1989; Ford \& Scott, 2006; Suazo-Ortuño et al., 2008; Urbina-Cardona, Olivares-Pérez, \& Reynoso, 2006; Thomas, Morrison, Winder, \& Morley, 2011; Mendenhall et al., 2014). Therefore, it may be that the conserved, seasonally dry forest of Chamela is not an adequate habitat for this species to occur in high numbers. Nevertheless, towards the end of the rainy season, we observed clutches of L. forreri in submerged vegetation in Arroyo Zarco, indicating reproductive activity of this anuran species at this site. 
In general, species with higher numbers of individuals were widely distributed among sites. In contrast, $R$. horribilis and I. mazatlanensis were rare during sampling weeks in both years, and eggs or larvae of these species were not recorded. In the case of $R$. horribilis, although we frequently observed individuals near the Chamela Station facilities, a small number of adults were recorded along the arroyos (never in amplexus). The lack of eggs or larvae of this species in the streams during the sampling weeks suggests that $R$. horribilis was not breeding at this time. $R$. horribilis is known to be a sporadic breeder that does not show a clear reproductive pattern (Crump, 1974), and appears to be an opportunistic species that can breed practically at any time when adequate conditions exist. By comparison, $I$. mazatlanensis is considered a rare species in the area, and although clutches or tadpoles of this species were not identified, pairs in amplexus were observed, indicating that the species was reproductively active during the study period. The species, $D$. sartori, S. fodiens and $T$. typhonius were infrequent during the sampling periods. The reproductive activity of these species was strongly associated with heavy rains, so the low frequency of strong rains during this study could limit their presence in the streams.

We also determined a temporal segregation of anuran species, reflected in the number of individuals recorded and their occurrence in the streams. It was clear that rainfall and anuran breeding patterns were associated as suggested by a study in a similar ecosystem in French Guiana (Gottsberger \& Gruber, 2004). Some species, such as T. smithii and E. smaragdina, were recorded reproductively active during several weeks and showed a positive correlation with relative humidity and accumulated precipitation. On the other hand, whereas reproductive activity of species such as $\mathrm{A}$. dacnicolor and $H$. ustus also lasted several weeks, this had a negative relation with precipitation, declining with the increased accumulation of rainfall. T. smithii and E. smaragdina were the only two anurans actively breeding when streams filled with water and recorded a greater flow, suggesting that these species are adapted to reproduction in lotic environments. The rest of the species were observed to reproduce in lentic water bodies or with little current. In the anurans, $H$. variolosus, T. typhonius and $S$. fodiens weekly rainfall was positively correlated with their occurrence in streams. The importance of rains in explosive reproductive events for these species indicates that reproductive activity is strongly associated with specific patterns of precipitation, usually greater than $30 \mathrm{~mm}$ rain (García, 2003). In many tropical and subtropical regions, precipitation, temperature, and photoperiod have been considered as determinants for the regulation of reproductive activity of amphibians, although it is believed that temperature plays a secondary role since it is probably correlated with the occurrence of rain, particularly in regions with climatic seasonality (Heyer, 1973; Galatti, 1992; Duellman \& Trueb, 1994; Saenz et al., 2006; Schalk \& Saenz, 2016). Therefore, the present study corroborates the described pattern for seasonal tropical environments, showing the strong influence of rainfall as a trigger for reproductive activity in anurans, but also showed there is a temporal segregation of species at breeding sites, suggesting resource partitioning is occurring within this assemblage.

While almost all species were observed in higher numbers during or immediately after the rains, a few species such as $A$. dacnicolor and $H$. ustus were also present and reproductively active (males singing, pairs in amplexus, clutches and/or larvae) in the absence of rainfall. This could be related to characteristics of their reproductive modes, such as eggs placed on vegetation or rocks in the case of $A$. dacnicolor, and reproductive behavior that is mainly terrestrial in the case of $H$. ustus, allowing these species to adjust to the erratic regime of rains in the region.

In general, differences in reproductive phases have been interpreted as a possible mechanism to avoid interspecific competition (Crump, 1982; Bertoluci \& Rodrigues, 2002). However, during the two rainy seasons, 
we recorded an overlap in the occurrence of anuran species in all the temporal streams sampled. Therefore, it may be that during this period the differential use of microhabitat for reproduction could be favorable for coexistence of these anuran species. In these temporary streams, species showed a particular association with microhabitat types. The hylids are mainly arboreal and usually call from vegetation near water bodies (Duellman \& Trueb, 1994; Ponssa, 2004). Although most of the species studied here are hylids, some species show greater plasticity in the use of substrates or types of vegetation. (e.g. S. baudinii and $D$. spatulata). In addition, the availability of different types of vegetation and other substrates may be sufficient to meet the needs of the hylid species, making inter-specific competition unlikely; similar to that found in a community of anurans that live in permanent streams in Southern Brazil (Afonso \& Eterovick, 2007; Oliveira \& Eterovick, 2010). On the other hand, within the microhylids, $H$. variolosus is often found in leaf litter and in rock crevices, but calling and breeding in the water of pools, whereas $H$. ustus was found calling and in amplexing on leaf litter, sand, or rocks.

The patterns of reproduction observed in this study can be explained by the regime of rains in the region, which at the same time determines the patterns of occurrence of anuran species in temporary streams. We were unable to determine a specific pattern of reproductive activity and microhabitat use for species $L$. melanonotus, $L$. forreri and $R$. horribilis due to the low number of individuals recorded. However, clutches of $L$. forreri were observed on submerged vegetation when the streams were almost full, but they had little current.

Results from this study suggest that occupancy and reproductive activity of aquaticbreeding anuran species could be associated with the availability of pools and the pattern of heavy rains during the rainy season. Occurrence of aquatic-breeding adults is also related to climatic factors such as temperature, humidity and accumulated rainfall resulting in temporal and spatial segregation (mainly by microhabitat) of species. Factors such as competition and predation have been shown to be important in structuring communities of adults and larvae of anurans (Lawler \& Morin, 1993; Morin, 1987; Gascon, 1991; Eterovick \& Sazima, 2000; Azevedo-Ramos, Magnusson, $\&$ Bayliss, 1999), and therefore on the coexistence of species. Current and future investigation in the Chamela area will certainly produce important information to questions regarding amphibian community dynamics, not only for this protected forest but for the entire region.

\section{ACKNOWLEDGMENTS}

This work is part of a project funded by the program of support for research projects and technological innovation (PAPIIT, UNAM, IN204713) awarded to Andrés García. We appreciate the support given to student Martha Isabel Luna Gómez by the Posgrado en Ciencias Biológicas, UNAM and the CONACYT. We appreciate comments and suggestions made by Katherine Renton that improved considerably this manuscript both in terms of its content and its English version. We recognize the valuable collaboration in the field and laboratory of the following students Alfredo Esparza Orozco, Bibiana Larios Llamas, Eduardo Salvador Ávila González, Diana Abilene Ahuatzin Flores, Renan Tapia Orozco, Eliza Álvarez Grzybowska and Rocio Vanessa Moreno.

\section{RESUMEN}

Distribución espacial y temporal y uso de microhábitat de los anuros con reproducción acuática en un bosque seco estacional en Chamela, México. La distribución de los anfibios se ve afectada por factores bióticos y abióticos, la disponibilidad de recursos y las características de los sitios de reproducción. En particular, la actividad reproductiva de los anuros que habitan las zonas tropicales secas se ve afectada por las lluvias, que determinan la disponibilidad y calidad de los sitios de reproducción. En este estudio, se analizó la distribución espacial y temporal de los anuros en un bosque tropical seco en el oeste de México durante dos temporadas de lluvias (10 de julio- 4 de octubre 2013 y 26 de junio- 26 de septiembre 2014). Se tomaron datos sobre la presencia de 15 especies de anuros con reproducción acuática en cuatro arroyos temporales 
y su relación con la precipitación, la humedad y la temperatura. Se determinó la riqueza, abundancia y diversidad de especies en cada arroyo; así como, las diferencias en las estrategias de reproducción y el uso de microhábitats por cada especie. Las especies más abundantes fueron: Tlalocohyla smithii y Exerodonta smaragdina, mientras que las menos abundantes fueron Leptodactylus melanonotus e Incilius mazatlanensis. La mayor riqueza, abundancia y actividad reproductiva se registró en el arroyo con el mayor número de sitios para la reproducción (charcas). Encontramos una segregación temporal en la presencia y actividad reproductiva de las especies que se asoció principalmente con la precipitación. También se observó una superposición de especies en algunas semanas durante la temporada de lluvias. La mayoría de las especies utilizaron sustratos específicos para determinadas actividades (por ejemplo, puesta de huevos), pero utilizaron una variedad de microhábitats para otras actividades (por ejemplo, vocalización). Discutimos estas diferencias de comportamiento como factores que facilitan la coexistencia de estas especies de anuros en este ambiente durante la estación lluviosa.

Palabras clave: anfibios, estrategias de reproducción, estacionalidad del medio ambiente, actividad reproductiva, bosque tropical seco, desarrollo indirecto.

\section{REFERENCES}

Afonso, L. G., \& Eterovick, P. C. (2007). Microhabitat choice and differential use by anurans in forest rivers in southeastern Brazil. Journal of Natural History, 41, 937-948.

Azevedo-Ramos, C. B. A., Magnusson, W. E., \& Bayliss, P. (1999). Predation as the key factor structuring tadpole assemblages in a savanna area in Central America. Copeia, 22-33.

Bernarde, P. S., \& Anjos, L. (1999). Distribuição espacial e temporal da anurofauna no Parque Estadual Mata dos Godoy, Londrina, Paraná, Brasil. Comunicações do Museu de Ciencia e Tecnología, 12, 127-140.

Bertoluci, J. (1998). Annual patterns of breeding activity in Atlantic rainforest anurans. Journal of Herpetology, 32, 607-611.

Bertoluci, J., \& Rodrigues, M. T. (2002). Seasonal patterns of breeding activity of atlantic rainforest anurans at Boracéia, Southeastern Brazil. Amphibia-Reptilia, 23, 161-167.

Bullock, S. H. (1986). Climate of Chamela, Jalisco, and trends in the south coastal region of México. File for Meteorology, Geophysics and Bioclimatology, 36, 297-316.

Cardoso, A. J., Andrade, G. V., \& Haddad, C. F. B. (1989). Distribuição espacial em comunidades de anfíbios
(Anura) no sudeste do Brasil. Revista Brasileira de Biologia, 49, 241-249.

Carrasco, F. A. (1989). Contribución al conocimiento del ciclo reproductor y alimentación de una población de sapos Bufo marinus, en la costa de Chamela, Jalisco. (Tesis de Licenciatura). Universidad Nacional Autónoma de México, México, D. F., México.

Casas-Andreu, G. (1982). Reptiles y Anfibios de la Costa Suroeste de Jalisco, con aspectos sobre su ecología y biogeografia. (Tesis de Doctorado). Universidad Nacional Autónoma de México, México, D.F, México.

Ceballos, G., \& García, A. (1995). Conserving neotropical biodiversity: The role of dry forest in Western Mexico. Conservation Biology, 9, 1349-1356.

Ceballos, G., Szekely, A., García, A., Rodríguez, P., \& Noguera, F. A. (1999). Plan de Manejo de la Reserva de la Biósfera Chamela-Cuixmala. México, D.F.: Instituto Nacional de Ecología, SEMARNAP.

Crump, M. L. (1974). Reproductive strategies in a tropical anuran community. Miscellaneous Publication of the Museum of Natural History, University of Kansas, 61, 1-68.

Crump, M. L. (1982). Amphibian reproductive ecology on the community level. In Jr. N. J. Scott. (Ed.), Herpetofaunal Communities: A symposium of the study of amphibians and reptiles and the herpetologist league (pp. 21-36). Washington, DC: Widlife Reserch Report 13.

Crump, M. L., \& Scott, N. J. Jr. (1994). Visual encounter surveys. In W. R. Heyer, M. A. Donnely, R. W. McDiarmid, L. C. Hayeck, \& M. S. Foster (Eds.), Measuring and monitoring biological diversity, standard methods for amphibians (pp. 84-92). Washigton, DC: Smithsonian Institution Press.

Curi, L. M., Céspedez, J. A., \& Álvarez, B. B. (2014). Composición, distribución espacial y actividad de vocalización de un ensamble de anuros dentro de la región fitogeográfica del Chaco Oriental. Revista Mexicana de Biodiversidad, 85, 1197-1205.

Duellman, W. D., \& Trueb, L. (1994). Biology of Amphibians. Baltimore: The Johns Hopkins University Press.

Eterovick, P. C., \& Sazima, I. (2000). Structure of an anuran community in a montane meadow in southeastern Brazil: Effects of seasonality, habitat, and predation. Amphibia-Reptilia, 21, 439-461.

Ford, P. L., \& Scott, N. J. Jr. (2006). Community level analysis of opportunistically-breeding anurans in western México. Herpetological Natural History, 2, 177-182.

Frost, D. R. (2016). Amphibian Species of the World: an Online Reference. Version 6.0 (Date of access). 
Electronic Database accessible at http://research. amnh.org/herpetology/amphibia/index.html. American Museum of Natural History, New York, USA.

Galatti, U. (1992). Population biology of the frog Leptodactylus pentadactylus in a central amazonian rainforest. Journal of Herpetology, 26, 23-31.

García, A. (2003). Biogeography, ecology and conservation of the herpetofauna from western Mexico. (Tesis de Doctorado). University of New Mexico, New Mexico, United States of America.

García, A., \& Ceballos, G. (1994). Guía de campo de los reptiles y anfibios de la costa de Jalisco, México. México: Fundación Ecológica de Cuixmala, A.C., Instituto de Biología, Universidad Nacional Autónoma de México.

García, A., \& Cabrera-Reyes, A. E. (2008). Estacionalidad y estructura de la vegetación en la comunidad de anfibios y reptiles de la Estación de Biología Chamela, Jalisco, México. Acta Zoológica Mexicana, 24, 91-115.

García-Oliva, F., Maass, J. M., \& Galicia, L. (1995). Rainstorm analysis and rainfall erosivity of a seasonal tropical region with a strong cyclonic influence in the Pacific Coast of Mexico. Journal of Applied Meteorology, 11, 2491-2498.

Gascon, C. (1991). Population- and community-level analyses of species occurrences of central amazonian rainforest tadpoles. Ecology, 72, 1731-1746.

Gottsberger, B., \& Gruber, E. (2004). Temporal partitioning of reproductive activity in a neotropical anuran community. Journal of Tropical Ecology, 20, 271-280.

Heyer, W. R. (1973). Ecological interactions of frog larvae at a seasonal tropical location in Thailand. Journal of Herpetology, 7, 337-361.

Lawler, S. P., \& Morin, P. J. (1993). Temporal overlap, competition, and priority effects in larval anurans. Ecology, 74, 174-182.

Lott, E. J., Bullock, S. H., \& Solis-Magallanes, J. A. (1987). Floristic diversity and structure of upland and arroyo forests of coastal Jalisco. Biotropica, $19,228-235$.

Mendenhall, C. D., Frishkoff, L. O., Santos-Barrera, G., Pacheco, J., Mesfun, E., Mendoza, F., \& Pringle, R. M. (2014). Countryside biogeography of neotropical reptiles and amphibians. Ecology, 95, 856-870.
Moreira, G., \& Lima, A. P. (1991). Seasonal patterns of juvenile recruitment and reproduction in four species of leaf litter frogs in central Amazonia. Herpetologica, 47, 295-300.

Morin, P. J. (1987). Predation, breeding asynchrony, and the outcome of competition among treefrog tadpoles. Ecology, 68, 675-683.

Oliveira, F. F. R., \& Eterovick, P. C. (2010). Patterns of spatial distribution and microhabitat use by syntopic anuran species along permanent lotic ecosystems in the cerrado of southeastern Brazil. Herpetologica, $2,159-171$

Ponssa, M. L. (2004). Utilización espacial y temporal de una comunidad de anuros de Kent's Marsh (Gamboa, Panamá). Revista Española de Herpetología, 8, 5-18.

Pough, H. F., Stewart, M. M., \& Thomas, R. G. (1977). Physiological basis of habitat partitioning in Jamaican Eleutherodactylus. Oecologia, 24, 285-293.

Ramirez-Bautista, A. (1994). Manual y claves ilustradas de los anfibios y reptiles de la Región de Chamela. Jalisco, México: Cuadernos del Instituto de Biología 23, Universidad Nacional Autónoma de México.

Ramírez-Bautista, A., \& García, A. (2002). Diversidad de la herpetofauna de la región de Chamela. In F. Noguera, J. H. Vega-Rivera, A. N. García-Aldrete \& M. Quesada-Avendaño (Eds.), Historia Natural de Chamela (pp. 251-263). México, DF: Instituto de Biología, UNAM.

Rossa-Feres, D., \& Jim, J. (2001): Similaridade do sítio de vocalização em uma comunidade de anfíbios anuros na região noroeste do Estado de São Paulo, Brasil. Revista Brasileira de Zoología, 18, 439-454.

Saenz, D., Fitzgerald, L. A., Baum, K. A., \& Conner, R. M. (2006). Abiotic correlates of anuran calling phenology: the importance of rain, temperature, and season. Herpetological Monographs, 1, 64-82.

Santos, T. G., Rossa-Feres, D. C., \& Asatti, L. C. (2007). Diversidade e distribuição espaço-temporal de anuros em região com pronunciada estação seca no sudeste do Brasil. Iheringia, Série Zoologia, 97, 37-49.

Schalk, C. M., \& Saenz, D. (2016). Environmental drivers of anuran calling phenology in a seasonal Neotropical ecosystem. Austral Ecology, 41, 16-27.

Suazo-Ortuño, I., Alvarado-Díaz, J., \& Martínez-Ramos, M. (2008). Effects of conversion of dry tropical forest to agricultural mosaic on herpeto faunal assemblages. Conservation Biology, 22, 362-374. 
Thomas, N., Morrison, C., Winder, L., \& Morley, C. (2011). Spatial distribution and habitat preferences of co-ocurring vertebrate species: case study of an endangered frog and introduce toad in Fiji. Pacific Conservation Biology, 1, 68-77.

Trejo, I., \& Dirzo, R. (2000). Deforestation of seasonally dry tropical forest: A national and local analysis in Mexico. Biological Conservation, 94, 133-142.

Urbina-Cardona, J. N., Olivares-Pérez, M., \& Reynoso, V. H. (2006). Herpetofauna diversity and microenvironment correlates across a pasture-edge-interior ecotone in tropical rainforest fragments in the Los Tuxtlas
Biosphere Reserve of Veracruz, Mexico. Biological Conservation, 132, 61-75.

Vasconcelos, T. S., \& Rossa-Feres, D. C. (2005). Diversidade, distribução espacial e temporal de anfibios anuros (Amphibia, Anura) na região noroeste do estado de São Paulo, Brasil. Biota Neotropica, 5, 1-14.

Zimmerman, B. L. (1994). Audio strip transects. In W. R. Heyer, M. A. Donelly, R. W. McDiarmid, L. C. Hayeck, \& M. S. Foster (Eds.), Measuring and monitoring biological diversity, standard methods for amphibians (pp. 84-92). Washington, DC: Smithsonian Institution Press. 